\title{
INTERPRETASI MAKNA HADIS MENCEGAH KEMUNGKARAN DI TENGAH BERTABURNYA KEJAHATAN
}

\author{
Sanusi \\ Program Studi Komunikasi dan Penyiaran Islam Fakultas Ushuluddin Adab dan Dakwah IAIN Langsa \\ Jl. Meurandeh, Langsa, 24411, Aceh, Indonesia \\ Email: Sanusi25@yahoo.com.
}

\begin{abstract}
This article discuss about a hadith from Muslim which said that we asked to prevent anybody from bad deed by our hand if we able, but if it is unable to do it verbally, then at least we feel dislike with our heart. That hadith will be understood in the various context that occur in our society. There are some people who like to be arrogant, the rulers who do injustice, and also there are some people who dislike the goodness and tend to badness. This article asserts that nahi munkar requires preparation and courage of every Muslim to do it. So it is very unfortunate if Muslims today do not have courage and ability to implement nahi munkar by hand and spoken to them, because they only able to feel dislike by their heart. Such an attitude like that is proof of the weakness of faith.
\end{abstract}

Keywords: Interpretation, Bad Deed, Badness

\begin{abstract}
Abstrak
Artikel mengkaji tentang hadis riwayat Muslim, yang mengatakan bahwa mencegah kemungkaran hendaklah dengan tangan, jika tidak mampu dengan lisan, selanjutnya dengan hati. Hadis tersebut akan diinterpretasi dalam konteks berbagai kecenderungan yang terjadi pada sebagian masyarakat. Ada orang yang suka menyombongkan diri, penguasa yang berbuat zalim, ada pula orang yang menentang kebaikan dan mengajak kepada keburukan serta kejahatan. Artikel ini menegaskan bahwa bahwa nahi munkar memerlukan persiapan dan keberanian dari setiap Muslim. Sehingga sangat disayangkan, jika umat Islam saat ini tidak memiliki keberanian dan kesanggupan melaksanakan nahi munkar dengan tangan dan lisan mereka, karena hanya mampu mencegah dengan hati. Sikap seperti ini adalah bukti kelemahan iman.
\end{abstract}

Kata Kunci: Interpretasi, Kemungkaran, Kejahatan

\section{Pendahuluan}

Da'wah Islämiyah yang bernadakan amar dan nahī, memerlukan adanya satu kekuatan yang tangguh; adanya satu organisasi yang militan, karena orang celaka yang terus membangkang terhadap dakwah yang bernadakan lembut, juga menyusun kekuatan dan organisasi dalam sikapnya menentang dakwah, seperti yang dijelaskan Allah:

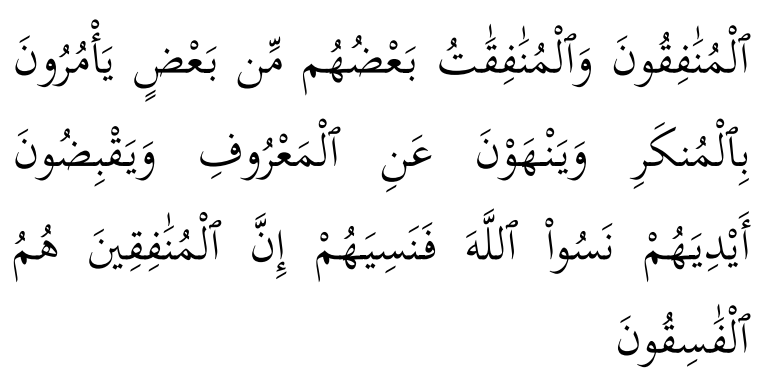

Orang-orang munafik, baik pria ataupun wanita, mereka bahu membahu dalam menyuruh berbuat mungkar, melarang berbuat makruf dan mereka mengepalkan tangannya. Mereka melupakan Allah, lantas Allah melupakan mereka. Se- 
sungguhnya orang-orang munafik adalah orang-orang yang fasik. ${ }^{1}$

Untuk mengimbangi kekuatan mereka; kekuatan orang celaka itu, maka orang-orang beriman haruslah menyusun kekuatan pula, harus bahu membahu dalam menjalankan dakwah.

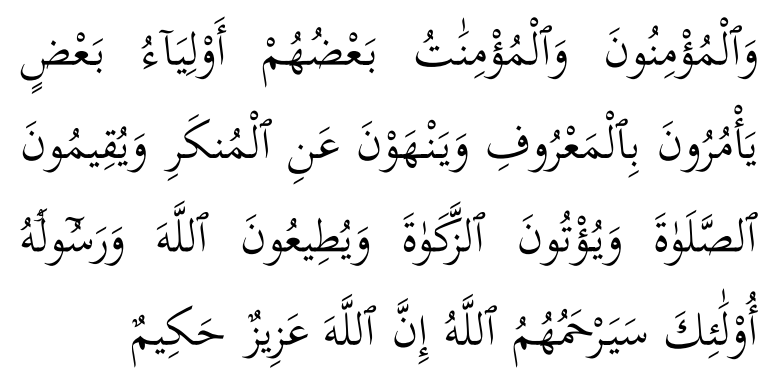

Dan orang-orang yang beriman, baik pria ataupun wanita, mereka bahu membahu dalam menyuruh makruf, melarang mungkar, mendirikan shalat, membayar zakat, mentaati Allah dan Rasul-Nya, Allah akan memberi rahmat kepada mereka, sesungguhnya Allah Maha Perkasa dan Maha Bijaksana. ${ }^{2}$

Ayat-ayat Alquran di atas mendalilkan, bahwa mendakwahkan amar makruf dan nahi mungkar kepada manusia, memerlukan adanya organisasi dan kekuatan pendukungnya, demikian tulis Muhammad Izzah Duruzah mengenai masalah ini. Selanjutnya tulisan beliau saya ikhtisarkan sebagai berikut: Ayat-ayat ini telah mendorong kebanyakan ulama untuk berpendapat, bahwa melaksanakan amar makruf dan nahi mungkar kewajihan

${ }^{1}$ Q.S. Al-Tawbah/9: 67. Departemen Agama RI, Al-Qur'an dan Terjemahannya (Solo: Tiga Serangkai Pustaka Mandiri, 2009), 197.

${ }^{2}$ Q.S. Al-Tawbah/9: 71. Departemen Agama RI, Al-Qur'an, 198. mutlak seluruh kaum muslimin, yang untuk menanggulanginya dengan sungguh sungguh perlu berdiri satu organisasi yang kuat dalam tiap-tiap masyarakat Islam.

Apabila tidak ada seorangpun dan anggota masyarakat yang melaksanakan tugas dakwah tersebut, maka berdosalah seluruh masyarakat. Pekerjaannya menjadi terbengkalai dan ikatan-ikatannya menjadi longgar dan putus, selama pribadipribadinya tetap melihat kemungkaran tetapi tidak mencegahnya, dan membiarkan kemakrufan tersia-sia tidak dilaksanakannya.

Ada sebagian mujtahid berpendapat, bahwa mendakwahkan amar makruf dan nahi mungkar harus dilakukan dengan kekuatan apabila keadaan memungkinkan dan para pelaksanaannya memandang bahwa dengan itu baru dakwahnya berhasil. Bahkan ada ulama yang berpendapat, bahkan kekuatan harus dipergunakan tidak memandang waktu dan tempat.

Mendakwahkan amar makruf dan nahi mungkar amat penting bagi kehidupan masyarakat, yang anggota-anggotanya agar bahu membahu membina kebaikan dan berdakwah kepadanya menegakkan kebenaran dan kemaslahatan; mencegah kejahatan dan kedurjanaan dengan segala jalan yang mungkin.

Kenyataannya bahwa kewajiban itu bersifat wajib dalam agama menyebabkan 
kepentingan dan kekuatannya menjadi bertambah. Para pelaksananya memandang dirinya terpanggil untuk melaksanan tugas suci itu. Mereka akan berdosa kalau meninggalkannya seperti halnya dengan orang-orang yang menerima dakwah. Mereka merasa terpanggil melaksanakan kewajiban keagamaan. Mereka merasa berdosa kalau tidak melaksanakannya.

Ini yang menyebabkan tuntunan Alquran berada di puncak keberhasilan pendidikan dan pengilhamannya dalam pencurahan kewajiban keagamaan ke dalam hati umat Islam dengan kekuatan dan pemantapan ini. $^{3}$

\section{Pengertian Makruf dan Mungkar}

Makruf dan mungkar adalah dua kata-kata umum. Kata yang pertama mencakup segala apa yang dikenal bahwa patut, baik dan benar, mengenai akhlak, dan adat istiadat. Makruf juga merupakan segala perbuatan yang faedah dan berkahnya kembali kepada pribadi dan masyarakat. Makruf tidak ada di dalamnya pemaksaan, kemesuman, kedurjanaan, dan segala hal buruk lainnya. Kata mungkar mencakup segala apa yang dikenal bahwa ia jahat, berbahaya dan keji. Mungkar juga terkait dengan akhlak, adat istiadat dan perbuatan. Mungkar mengakibatkan adanya bencana

${ }^{3}$ A. Hasjmy, Dustur Dakwah Menurut AlQur'an (Jakarta: Bulan Bintang, 1994), 241-243. dan kemelaratan pada pribadi dan masyarakat. Jadi, mungkar mencakup unsur kemesuman, pencurangan, kedurjanaan, dan hal buruk lainnya.

Dalam Alquran terdapat ayat-ayat yang memberi pengertian makruf, seperti dalam contoh-contoh di bawah ini:

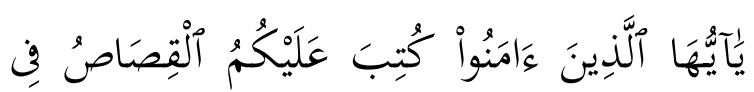

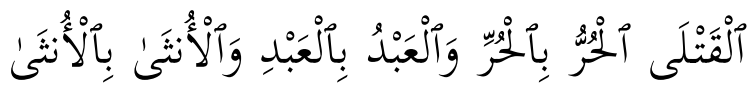

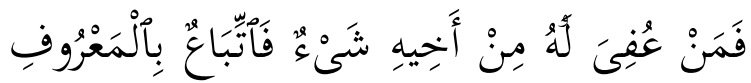

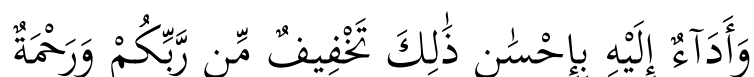

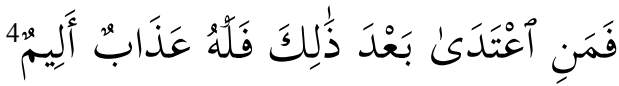

Wahai orang-orang yang beriman. Diwajibkan atasmu kisas dalam hubungan dengan orang-orang yang dibunuh. Orang merdeka dengan orang merdeka; budak dengan budak; wanita dengan wanita. Karena itu, siapa yang diberi sekedar kemaafan oleh saudara yang terbunuh, maka dia telah berbuat makruf dan hendaklah diberikan kepadanya ihsan. Yang demikian itu adalah pengentengan dan rahmat dan Tuhan-mu. Sebab itu, siapa bersikap bermusuhan setelah itu, untuknya disediakan azab yang dahsyat.

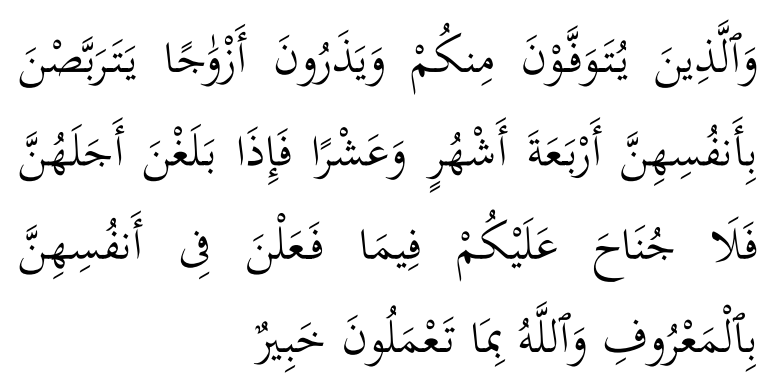

Orang-orang yang meninggal dunia di antara kamu dan meninggalkan

${ }^{4}$ Q.S. AI-Baqarah/2: 178. 
istri-istri hendaklah para istri bersabar empat bulan sepuluh hari. Apabila telah sampai waktunya, tidak ada kesalahan bagimu tentang perbuatan makruf mereka terhadap dirinya, dan Allah mengetahui apa yang kamu kerjakan. ${ }^{5}$

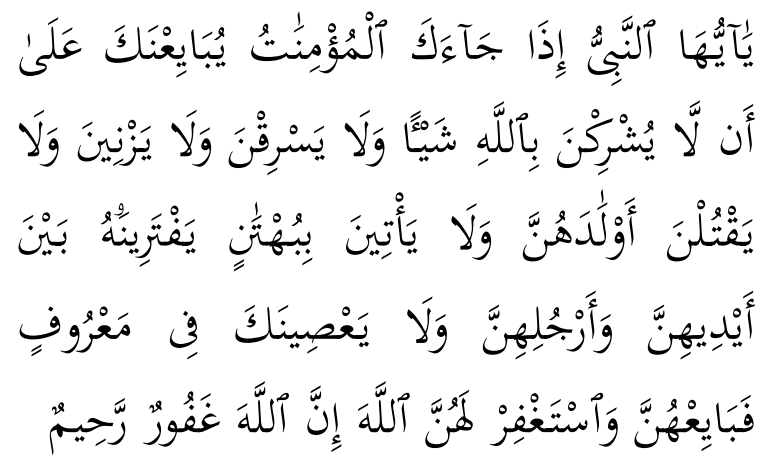

Wahai Nabi, apabila datang kepada engkau para wanita yang beriman untuk mengikat janji setia, bahwa mereka tidakakan mempersekutukan sesuatu dengan Allah; dan tidak akan mencuri; tidakakan berzina; tidak akan membunuh anak-anak mereka: tidak membuat kedustaan di antara kaki dan tangannya; tidak akan mendurhakai engkau dalam berbuat makruf, maka terimalah janji setiamereka dan mintalah ampunan Allah untuk mereka; sesungguhnya Allah Maha Pengampun, Maha Penyayang. ${ }^{6}$

Penegasan Alquran tentang keumuman istilah makruf, dengan sendirinya meliputi keumuman istilah mungkar.

Ada banyak pengertian umum makruf dan melarang mungkar, di antaranya: Usaha untuk membina kebenaran, keadilan dan kemerdekaan;

${ }^{5}$ Q.S. AI-Baqarah/2: 234. Departemen Agama RI, Al-Qur'an, 20.

${ }^{6}$ Q.S. Al-Mumtahanah/60: 12. Departemen Agama RI, Al-Qur'an, 551. untuk mencegah kezaliman, perbudakan dan hawa nafsu; menegakkan kekuasaan yang adil menurut teks dan ruh Alquran, menentang kekuasaan yang kejam bertangan besi, dan sebagainya.

Atas landasan ini Alquran mewajibkan kaum muslimin untuk membina kekuasaan yang adil dalam Islam. Alquran juga menentang kezaliman, kedurjanaan dan pelanggaran terhadap hakhak asasi manusia.

Demikian pula, termasuk dalam pengertian umum amar makruf dan nahi mungkar yaitu menyuruh berbuat kebajikan dan kasih sayang kepada golongan lemah, melaksanakan rencana-rencana perbaikan akhlak, mencegah berbuat kejahatan dan perbuatan-perbuatan yang merusakkan akhlak dan masyarakat. Atas dasar ini, Islam mewajibkan umat Islam untuk membina kesejahteraan masyarakat yang berasaskan kebaikan, sendi akhlak, dan gotong royong.

Dari segala bentuk yang disebutkan di atas, patutlah dirumuskan suatu kaidah umum, bahwa segala larangan yang tersebut dalam Alquran dan Sunah termasuk dalam pengertian kemungkaran. Segala yang disuruh dan dipuji dalam Alquran dan Sunah termasuk dalam pengertian kemakrufan.

Jadi, sangat banyak bentuk larangan, seperti: berdusta, menggunjing, 
mengumpat, berbuat dosa, berbuat jahat, melanggar hak-hak asasi, berzina, membunuh, menuduh, mencuri, menipu, merampok, boros, kikir, berbifat kerusakan di atas bumi, dan sebagainya. Sama banyaknya dengan bentuk suruhan, seperti: Kebenaran, menghormati hak orang lain darahnya, hartanya kehormatannya, menunaikan janji, berjihad di jalan Allah, berbuat kebaikan dan kebajikan, dan lainlain. Apabila kita perhatikan semua bentuk tersebut, kita akan dapati bahwa mungkin beragam bentuk kemungkaran dan kemakrufan menurut tempat dan zamannya.

Masih ada urusan-urusan kehidupan yang tidak termaktub dalam Alquran. Sebab sudah dicukupkan dengan garis-garis besar dan ajaran umum yang terkandung di dalam Alquran. Dapat disebut sebagai satu kaidah umum, bahwa suatu urusan khusus dan urusan umum yang tidak tercantum dalam Alquran dan Sunah, maka bentuk kemakrufan dan kemungkaran tergantung pada hasil pemikiran ahli ilmu di satu pihak, dan fonemana masyarakat di pihak lain. Fenomena di sini tentu sangat terkait dengan penerimaan umum atau penolakan umum dari berbagai lapisan masyarakat. Pada sisi yang lain, ukuran kemakrufan dan kemungkaran itu harus tetap berada pada batas-batas bimbingan dan ajaran Alquran dan Sunah secara umum.
Kita juga dapat merumuskan sebuah prinsip, bahwa suatu masalah yang tidak termaktub dalam Alquran dan Sunah, maka ia akan membentuk diri sesuai dengan keadaan waktu dan tempat. Jika sesuatu itu dianggap mungkar pada satu zaman dan tempat, maka di waktu dan tempat yang lain boleh jadi dipandang sebagai suatu perbuatan makruf, sehingga berubah pengertian sesuatu, karena perubahan waktu dan tempat. Di sinilah letak rahasia mukjizat Alquran yang abadi. ${ }^{7}$

Selanjutnya Seperti tablig, amar makruf dan nahi munkar merupakan keharusan agama dan tuntutan iman. Amar makruf merupakan bagian penting dalam dakwah. Amar makruf dan nahi munkar merupakan kewajiban umat Islam baik sebagai individu maupun umat. Amar makruf dan nahi munkar menjadi ciri dan karakter umat Islam yang menonjol. Ciri inilah yang membedakan masyarakat Islam dengan masyarakat lain. Masyarakat Islam adalah masyarakat yang memiliki kepedulian terhadap kebaikan dan petunjuk Allah. Umat Islam merupakan masyarakat yang selalu bekerjasama dan bahu membahu dalam membangun kebaikan masyarakat dan memerangi kajahatan.

Sebagai umat terbaik, umat Islam berdasarkan ayat ini berkewajiban melakukan tiga hal. Pertama, amar makruf,

\footnotetext{
${ }^{7}$ A. Hasjmy, Dustur, 241-243.
} 
menyuruh manusia kepada kebaikan. Kata ma'ruf berarti sesuatu yang baik atau yang dipandang sebagai kebaikan, merupakan sesuatu yang dipandang baik oleh agama dan pemikiran (akal). Menurut Qutb, makruf adalah sistem dan tata nilai Islam itu sendiri. Baginya, amar makruf adalah usaha menanamkan dan membudayakan nilai-nilai Islam dalam kenyataan individu, keluarga, dan masyarakat.

Kedua, nahi mungkar berarti mencegah manusia dari kemungkaran. Mungkar adalah lawan dan majruf, berarti sesuatu yang buruk atau yang dipandang huruk oleh agama dan pemikiran (akal). Menurut Sayyid Quṭb, munkar adalah sistem dan tata-nilai jahiliyah. Jahiliyah, seperti telah disinggung di muka, bukanlah suatu fase kehidupan pada masa lalu, tetapi sistem hidup dan tata nilai yang bersumber dan pemikiran yang menolak ketuhanan Allah swt. Sistem dan tata-nilai ini mempengaruhi pikiran, sikap, prilaku, dan kebudayaan manusia baik pada masa lalu, masa kini maupun masa datang. Dalam perspektif ini, nahi mungkar berarti mengenyahkan sistem dan tata nilai jahiliyah, dan menggantikannya dengan sistem dan tata-nilai Islami. ${ }^{8}$

${ }^{8}$ A. Ilyas Ismail, Paradigma Dakwah Sayyid Quthub "Rekonstruksi Pemikiran Dakwah Harakah (Jakarta: Penamadani, 2006), 168.
Ketiga, iman kepada Allah swt. Ini merupakan dasar dari dua tugas sebelumnya. Menurut Quṭb, iman harus menjadi pusat orientasi dan setiap kegiatan khayr ummah. Amar makruf dan nahi mungkar yang dilakukan haruslah dalam kerangka iman dan ibadah kepada Allah swt. Iman juga harus menjadi satu-satunya kriteria penilaian (mīzān) dalam menetapkan mana yang makruf dan mana yang mungkar. Jadi, kriteria penilaian itu, menurut Quṭb, bukanlah pandangan dan hawa nafsu manusia yang sangat parsial, subjektif, dan tidak pernah bebas dari kepentingan sesaat.

Amar makruf dan nahi mungkar ini, menurut Quṭb, merupakan pekerjaan atau tugas aktif (al-'amāl al-ijābìyah) yang harus dilakukan untuk mewujudkan masyarakat yang baik dan untuk menjaga dan memelihara kehidupan masyarakat dari keburukan dan kejahatan. Perintah amar makruf dan nahi mungkar, menurut Quṭb, juga dimaksudkan sebagai ikhtiar mewujudkan kedamaian dan kebahagiaan masyarakat. Kebahagiaan masyarakat atau umat itu, tidak akan terwujud, kecuali bila kebaikan menjadi unsur dominan dalam masyarakat itu. Dominasi kebaikan ini harus diupayakan melalui pembudayaan nilai-nilai Islam (amar makruf) di satu pihak, dan kontrol sosial (nahi mungkar) terhadap berbagai penyimpangan dan 
ketimpangan sosial yang teriadi dalam masyarakat di lain pihak.

Jadi, amar makruf dan nahi mungkar dalam pengertian ini dimaksudkan untuk menjaga kelangsungan dan kemajuan masyarakat Islam. Ketentuan ini berlaku setelah masyarakat Islam itu sendiri terbentuk. Bila masyarakat Islam itu belum terbentuk, maka tugas amar makruf yang terpenting dan yang mula-mula harus dilakukan. Menurut Quṭb, tugas itu ialah mengokohkan akidah tauhid dan membangun masyarakat Islam atas dasar aqidah tauhid itu. Inilah, masih menurut menurut Quṭb, tugas amar makruflah yang terbesar (al-amr bi al-ma'rūf al-akbar). Sedang nahi munkar yang terbesar dan harus menjadi prioritas utama (al-nahy 'an al-munkar al-akbar) ialah menghancurkan țāgūt dan membebaskan manusia dan penyembahan kepada selain Allah. Ini berarti, amar makruf, menurut Quṭ, tidak boleh dimulai dari hal kecil yang merupakan cabang (far'), tetapi harus dimulai dan bertitik tolak dan makruf yang terbesar yang merupakan sumber kebaikan. Begitu pula nahi mungkar, harus dimulai dan kemungkaran yang terbesar yang menjadi sumber dan biang dan semua keburukan dan kejahatan. ${ }^{9}$

Proses amar makruf dan nahi mungkar, menurut Quṭb, harus

\footnotetext{
${ }^{9}$ Ismail, Paradigma, 168.
}

memperhatikan akar permasalahan yang terjadi dalam masyarakat. Tanpa memperhatikan masalah ini, tugas amar makruf dan nahi munkar ini, dapat dipastikan tidak akan berjalan efektif. Dalam kaitan ini, Quṭb memberikan beberapa contoh. Semua kegiatan ekonomi dalam masyarakat yang didasarkan pada sistem riba, maka seluruh harta yang diperoleh menjadi haram, sehingga tidakseorang pun dapat makan dan harta yang halal. Hal ini disebabkan karena sistem sosial dan ekonominya tidak didasarkan kepada Syariat AIlah.

Begitu juga, manusia tidak akan dapat dicegah dan keburukan dalam masyarakat yang undang-undangnya tidak melarang perzinahan dan tidak menghukum pelakunya dengan hukum atau syariat Allah. Masyarakat tidak pula dapat dicegah dari perbuatan mabuk-mabukan, karena undang-undangnya memperbolehkan jualbeli minuman keras dan tidak menghukum para pelakunya. Masyarakat yang tidak beriman kepada Allah, juga tidak dapat dicegah dari memaki dan memusuhi agama Allah. Masyarakat yang tidak mengakui kekuasaan Allah swt. dan tidak menyembah kepada-Nya, melainkan menyembah kepada tuhan-tuhan selain Allah, juga tidak bisa dicegah dari hal yang sama. Ini semua menurut Quṭb, memberi pelajaran bahwa amar makruf dan nahi mungkar harus 
dilakukan sesuai dengan tantangan dan kebutuhan yang terjadi dalam masyarakat.

Amar makruf dan nahi mungkar sebagai bagian dan proses membangun dan mewujudkan sistem Islam. Hal ini tentu bukanlah pekerjaan yang ringan, bahkan sangat berat. Itu juga harus didasarkan pada kenyataan dari berbagai kecenderungan yang terjadi dalam masyarakat. Di antara mereka terdapat orang yang suka menyombongkan diri, juga ada penguasa yang berbuat zalim dan sewenang-wenang. Ada juga di antara mereka pemalas yang tidak mau diajak maju dan bekerja keras. Ada pula orang yang menentang kebaikan, menyuruh manusia pada keburukan dan kejahatan. Kenyataan demikian menghendaki agar amar makruf dan nahi mungkar harus selalu diupayakan dan dilaksanakan sedapat mungkin baik dengan tangan, lisan maupun dengan hati. Seperti sabda Nabi saw.:

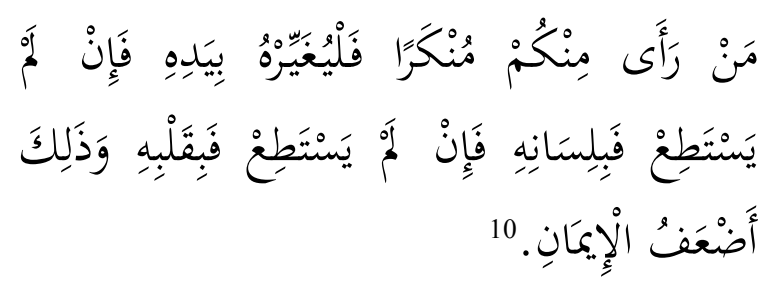

"Barangsiapa di antara kamu melihat kemungkaran, maka hendaklah ia mengubahnya dengan tangannya. Jika tidak mampu, maka ia harus mengubahnya dengan lisannya. Jika tidak mampu, maka ia harus

${ }^{10} \mathrm{Abū}$ al-Husayn Muslim bin al-Hajjāj alQusyayrī al-Naysābūrī, Șah̄īh Muslim, cet. I (Saudi Arabia: Dār al-Mugnī, 1998), 44. mengubahnya dengan batinnya. Namun, yang demikian adalah selemah-lemahnya iman."

Nahi munkar seperti disebut dalam hadis ini memerlukan kesiapan dan keberanian dari setiap Muslim. Sungguh disayangkan, kata Quṭb, bila kini umat Islam tidak memiliki keberanian dan kesanggupan melaksanakan nahi mungkar dengan tangan dan dengan lisan mereka. Lalu, yang tinggal hanyalah selemah-lemah iman, yaitu mencegah kemungkaran dengan hati mereka. Sesunggunya ini merupakan batas minimal yang tidak bisa tidak, mesti dilakukan, bila mereka betul-betul sebagai seorang muslim.

Allah swt. mengecam keras dan mengutuk orang-orang yang membiarkan kemungkaran seperti kecaman dan kutukan Allah swt. terhadap Bani Israil. Allah berfirman:

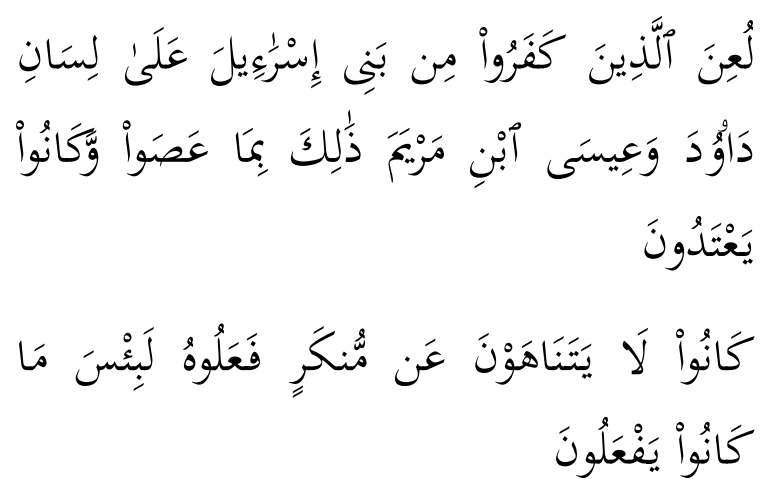

"Telah dilaknati orang-orang kafir dari Bani Israil dengan lisan Dāwud dan 'Is $\bar{a}$ putera Maryam. Yang demikian itu, disebabkan mereka durhaka dan selalu melampaui batas. Mereka satu sama lain selalu tidak melarang tindakan munkar yang 
mereka perbuat. Sesunggunya amat buruklah apa yang selalu mereka perbuat itu., "l

Dalam ayat lain Allah mengingatkan orang-orang beriman agar tidak membiarkan berbagai tindak kejahatan terjadi di depan mereka. Apabila mereka acuh tak acuh terhadap kejahatan itu, maka azab Allah akan menimpa mereka pula. Allah berfirman:

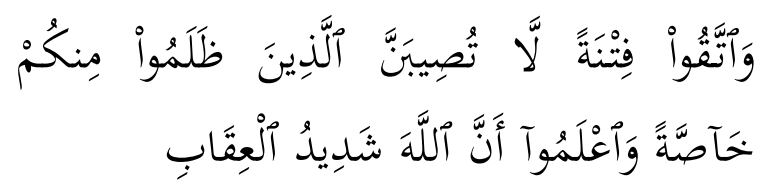

"Dan peliharalah kamu dari siksaan yang tidak khusus menimpa orangorang yang zalim saja di antara kamu. Dan ketahuilah bahwa Allah amat keras siksaan-Nya."12

Mengomentari ayat di atas, Sayyid Quṭb menyatakan bahwa suatu masyarakat yang membiarkan kezaliman dan tidak berusaha menghadapi orang-orang yang berbuat kezaliman itu, maka mereka layak mendapat hukuman seperti halnya orang orang yang berbuat zalim itu. Hal ini demikian, menurut Quṭb, karena Islam adalah sistem hidup yang secara aktif mengajarkan tanggung jawab sosial (manhaj takāfuli ijābi). Oleh karena itu, Islam tidak pernah membenarkan seseorang berpangku tangan dan berdiam diri, sementara berbagai tindak kejahatan dan

${ }^{11}$ Q.S. Al-Ma'idah/5: 78-79. Departemen Agama RI, Al-Qur'an, 121.

${ }^{12}$ Q.S. A1-Anfā1/8: 25. Departemen Agama RI, Al-Qur'an, 179. kezaliman terjadi di depan matanya. Sikap semacam ini, sama sekali tidak dapat ditolerir, dan tidak dapat membuat yang bersangkutan terhindar dan siksa Allah swt.

Tanggung jawab sosial dalam bentuk amar makruf dan nahi mungkar itu, menurut Quṭb, justru merupakan ajaran sosial Islam yang amat penting. Seorang mukmin, kata Quṭb, karena ajaran sosial ini, mesti mengembangkan karakter dan watak keumatan, watak kesatuan, dan watak saling membantu dan bekerjasama dalam mewujudkan kebaikan dan menolak keburukan. Karena watak saling membantu (ta' $\bar{a}$ wun) dan bekerjasama (tadāmun) ini, masyarakat atau umat Islam pada hakekatnya merupakan suatu komunitas yang sangat kokoh. Secara internal, umat Islam tidak terdapat di dalamnya unsurunsur perpecahan. Perpecahan yang terjadi dalam masyarakat Islam pastilah karena faktor-faktor eksternal yang datang dan luar ajaran dan akidah Islam.

Watak yang sejati dan masyarakat Islam seperti dikemukakan di atas, digambarkan dengan jelas dalam ayat ini:

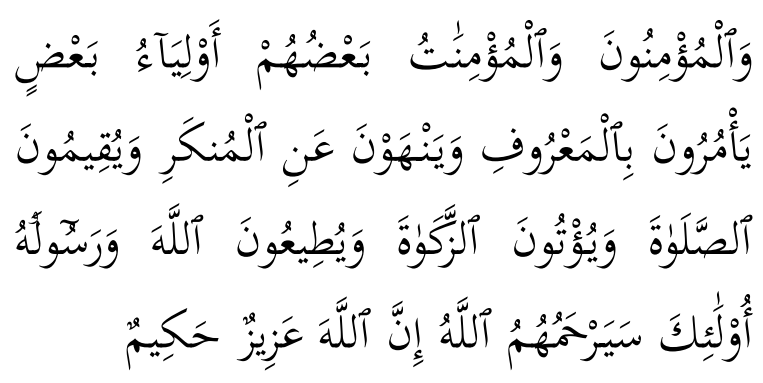


"Dan orang-orang yang beriman, laki-laki dan perempuan, sebahagian mereka (adalah) penolong bagi sebahagian yang lain. Mereka menyuruh (mengerjakan) yang makruf mencegah dan yang mungkar, mendirikan salat, menunaikan zakat, dan mereka taat kepada Allah dan Rasul-Nya. Mereka akan diberi rahmat oleh Allah. Sesungguhnya Allah Maha Perkasa lagi Maha Bijaksana. "13

Umat Islam seperti digambarkan ayat di atas, memiliki empat ciri yaitu menyuruh (manusia berbuat) yang makruf, mencegah manusia dari yang mungkar, mendirikan salat, dan menunaikan zakat. Empat sifat yang menjadi ciri kaum Muslim ini, menurut Quṭ, secara diametral berlawanan dengan sifat sifat orang-orang munafik, yaitu menyuruh manusia berbuat yang mungkar, mencegah manusia dan yang makruf, melupakan Allah, dan menimbun harta (kikir). Sedang rahmat Allah bagi umat Islam menjadi imbangan kutukan Allah atas kaum Munafik. ${ }^{14}$

\section{Tugas Umat Islam}

Amar makruf dan nahi mungkar adalah tugas mutlak bagi umat Islam. Seperti yang telah ditugaskan oleh ayat-ayat dalam Alquran.

Seperti halnya amar makruf dan nahi mungkar menjadi kewajiban tiap-tiap

\footnotetext{
${ }^{13}$ Q.S. Al-Tawbah/9: 71. Departemen Agama RI, Al-Qur'an, 198.

${ }^{14}$ Ismail, Paradigma, 168.
}

pribadi muslim, maka demikian pula dibebankan kepada umat Islam, bahkan kepada Negara. Hal ini berdasarkan adanya nas yang pasti tentang hal tersebut, yaitu surah Āli 'Imrān ayat 104, misalnya. Ayat ini mendalilkan adanya kewajiban atas umat Islam. Sementara surah al-Hajj ayat 41 menegaskan adanya kewajiban atas negara negara.

Surah al-Nisa', al-A'rāf, dan Luqmān hanya mengandung ayat-ayat yang mewajibkan kepada pribadi:

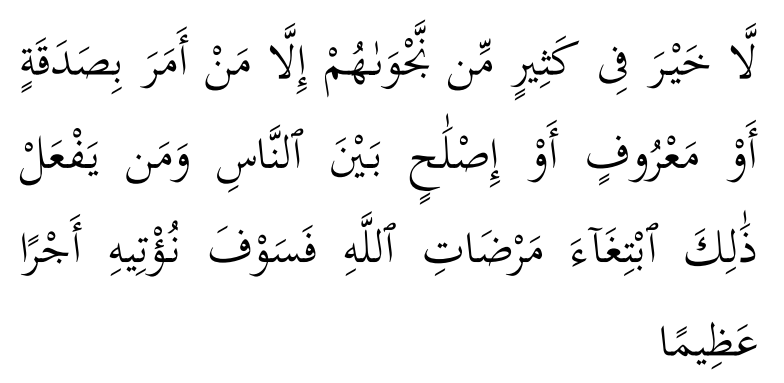

Tidak ada kebaikan apa-apa pada kebanyakan omongan mereka, kecuali orang yang menyuruh bersedekah, berbuat makruf dan menciptakan suasana damai kerelaan Allah, niscaya akan Kami berikan kepadanya pahala besar. ${ }^{15}$

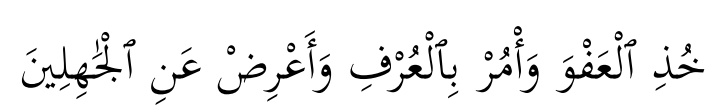

Berilah kemaafan, suruhlah berbuat makruf dan hindari dirimu dari orang jahil. ${ }^{16}$

${ }^{15}$ Q.S. Al-Nisa'/4: 114. Departemen Agama RI, Al-Qur'an, 97.

${ }^{16}$ Q.S. Al-A'rāf/7: 199. Departemen Agama RI, Al-Qur'an, 176. 


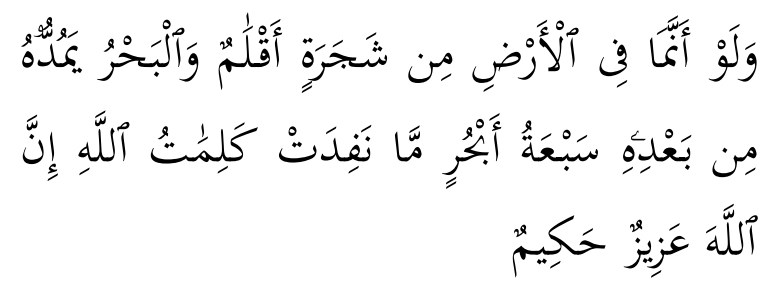

Dan seandainya pohon-pohon di bumi menjadi pena dan lautan dengan ditambah tujuh lautan lagi menjadi tinta, namun tidak akan habis-habisnya kalimat-kalimat Allah ditulisnya, sesungguhnya Allah Maha Perkasa dan Maha Bijaksana. ${ }^{17}$

\section{Landasan Hukum Dakwah}

Dakwah bisa disebut sebagai aktualisasi nilai-nilai Islam yang diterjemahkan ke dalam ajaran-ajaran Islam bagi upaya mewujudkan kebahagiaan hidup manusia di dunia ini. Untuk hal tersebut ada hukum normatif yang mengikat keharusan berdakwah. Hukum-hukum tersebut akan diuraikan dalam pembahasan tentang arti landasan berdakwah.

Kepastian hukum yang dimaksud adalah kepastian hukum atau penilaian hukum secara syariah. Kepastian hukum secara syariah, dakwah adalah wajib, sebagaimana tercantum dalam Alquran surah Āli ‘Imrān, ayat 104:
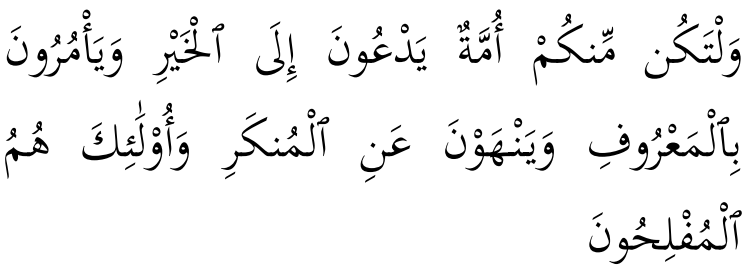
241-243.
Dan hendaklah ada di antara kamu segolongan umat yang menyeru kepada kebajikan, menyuruh kepada yang makruf dan mencegah dari yang mungkar merekalah orang-orang yang beruntung. ${ }^{18}$

Dalam ayat yang lain Allah berfirman:

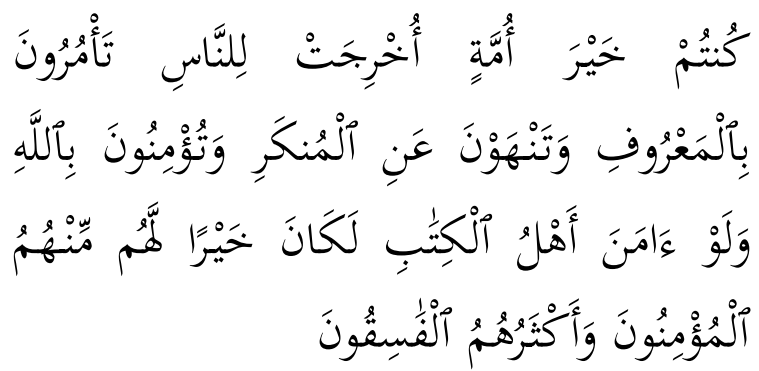

Kamu adalah umat yang terbaik yang dilahirkan untuk manusia, menyuruh kepada yang makruf, dan mencegah dari yang mungkar, dan beriman kepada Allah. Sekiranya ahli Kitab beriman, tentulah itu lebih baik bagi mereka, di antara mereka ada yang beriman, dan kebanyakan mereka adalah orang-orang yang fasik. ${ }^{19}$

Masalah yang timbul kemudian, adalah apakah kewajiban berdakwah itu merupakan kewajiban individual ataukah kewajiban kolektif? Menurut Abdul Karim Zaidan, bahwa huruf mim yang tertera dalam ayat tersebut mengandung arti yang menerangkan (li al-tabyīn) dan bukan mengandung arti yang menunjukkan sebagian (li al-tab ‘ịd).

Sehingga dengan demikian, kewajiban berdakwah adalah kewajiban individual atau fardu ain bagi setiap orang

${ }^{18}$ Q.S. Āli ‘Imrān/3: 104. Departemen Agama RI, Al-Qur'an, 63.

${ }^{19}$ Q.S. Āli 'Imrān/3: 110. Departemen Agama RI, Al-Qur'an, 64. 
DI TENGAH BERTABURNYA KEJAHATAN

Islam yang mukalaf. Tentu saja kewajiban ini sesuai dengan kemampuan masingmasing.

Memahami arti dan landasan hukum dakwah yang fardu ain tersebut dapat kita mengerti, bahwa Islam yang datang sebagai risalah terakhir yang memodifikasi ajaranajaran sebelumnya adalah merupakan risalah yang terkandung nilai-nilai humanis teosentris yang bersifat universal. Pengertian tersebut, berarti tidak terkecuali umat Islam atau bukan, semuanya adalah manusia yang harus mendapatkan risalah terakhir tersebut. Maka jika tidak adanya pewajiban secara ain (individual), tanggung jawab akan tergantung kepada kelompokkelompok tertentu secara kifayah. Hal ini menunjukkan bahwa agama Islam dari sisi ajarannya merupakan rahmat bagi alam semesta. $^{20}$

\section{Kesimpulan}

Dari beberapa penjelasan tersebut di atas dapat kita ambil kesimpulan bahwa amar makruf nahi mungkar itu merupakan kewajiban individual, dan menjadi tugas umat muslim. Makna dari interpretasi yang dari hadis nahi mungkar (demikian juga ayat-ayat amar makruf nahi mungkar) memberikan keterangan bahwa kita selaku umat Islam adalah umat yang terbaik untuk manusia. Apabila kita mampu menyuruh kepada yang makruf dan mencegah yang mungkar, maka kita termasuk kepada orang-orang yang beruntung. Nahi mungkar memerlukan kesiapan dan keberanian dari setiap orang Muslim untuk melakukannya. Sungguh disayangkan, bila saat ini umat Islam tidak memiliki keberanian dan kesanggupan melaksanakan nahi mungkar dengan tangan dan lisan mereka. Mereka hanya mampu mencegah dengan hatinya saja. Demikian itu menandakan selemahlemah iman.

\footnotetext{
${ }^{20}$ Samsul Munir Amin, Rekonstruksi Pemikiran Dakwah Islam (Jakarta: Amzah, 2008), 51.
} 


\section{Daftar Pustaka}

Alquran Karim

Abdullah, M. Amin. Dinamika Islam, Kultural: Pemetaan Atas Wacana Keislaman Kontemporer. Bandung: Mizan, 2000. . Studi Agama: Normativitas atau Historisitas? Yogyakarta: Pustaka Pelajar, 1996.

Abū Zahrah, Muḥammad. Al-'Alaqāt al-Dawliyyat fì al-Islām. Kairo: T.p., t.th. . Tārīkh al-Mażāhib al-Islāmiyyah. T.t.: Dār al-Fikr al-'Arabī, t.th. . Ușūl al-Fiqh. T.t.: Dār al-Fikr al-'Arabī, 1958.

Amin, Samsul Munir. Rekonstruksi Pemikiran Dakwah Islam. Jakarta: Amzah, 2008.

Departemen Agama RI. Al-Qur'an dan Terjemahannya. Solo: Tiga Serangkai Pustaka Mandiri, 2009.

Hasjmy, A. Dustur Dakwah Menurut Al-Qur'an Jakarta: Bulan Bintang, 1994.

Ismail, A. Ilyas. Paradigma Dakwah Sayyid Quthub "Rekonstruksi Pemikiran Dakwah Harakah. Jakarta: Penamadani, 2006.

al-Naysābūrī, Abū al-Ḥusayn Muslim bin al-Ḥajjāj al-Qusyayrī. Ṣaḥīh Muslim. Cet. I. Saudi Arabia: Dār al-Mugn̄̄, 1998. 
INTERPRETASI MAKNA HADIS MENCEGAH KEMUNGKARAN

DI TENGAH BERTABURNYA KEJAHATAN 